\title{
Editorial
}

\section{Octapeptide somatostatin-analogue therapy of Cushing's syndrome}

The currently available octapeptide somatostatin analogues octreotide (Sandostatin, Sandostatin LAR, Novartis, Basle, Switzerland) and somatuline (BIM 23014, Lanreotide, Beaufort-Ipsen, Paris, France) have beneficial effects in the treatment of various neuroendocrine tumour syndromes. These effects are mediated through specific membrane-associated somatostatin receptor subtypes (ssts) on the target tissues. ${ }^{1}$ Five different sst subtypes (sst ${ }_{1-5}$ ) have been cloned and characterised, and it was demonstrated that octapeptide somatostatin analogues bind with a high affinity to $\mathrm{sst}_{2}$ and $\mathrm{sst}_{5}$, show a low affinity to $\mathrm{sst}_{3}$, but no affinity to $\mathrm{sst}_{1}$ and $\mathrm{sst}_{4} \cdot{ }^{1}$ Tumours and metastases, which bear receptors for octapeptide analogues, can be visualised in vivo using gamma camera pictures obtained after injection of ${ }^{111}$ In-pentetreotide (OctreoScan, Mallinckrodt, Petten, The Netherlands). ${ }^{1}$

The possible therapeutic effects of octreotide have been studied in the different subclasses of Cushing's syndrome. Cushing's disease, which exclusively stands for the excessive secretion of (adreno)corticotropin (ACTH) by the pituitary, is the main variant of Cushing's syndrome, representing about $65-75 \%$ of patients. ${ }^{2}$ The five different ssts can be expressed by human corticotrophs. ${ }^{3}$ Studies in cultured human ACTH-secreting tumour cells have demonstrated that basal and corticotropin-releasing-factorstimulated ACTH release was only inhibited by somatostatin or octreotide if the cells were pre-cultured in a medium without glucocorticoids. ${ }^{4}$ In line with this, no suppressive effect of octreotide has been demonstrated in the majority of patients with untreated Cushing's disease, who have increased cortisol levels. ${ }^{6}$ In our experience, none of eight ACTH-secreting pituitary microadenomas and one macroadenoma showed an increased uptake of ${ }^{111} \mathrm{In}$ pentetreotide in vivo. However, ${ }^{111}$ In-pentetreotide scintigraphy (SRS) was positive for two invasive ACTH-secreting macroadenomas. ${ }^{7}$ In contrast, octapeptide somatostatin analogues are potent inhibitors of ACTH hypersecretion in patients with Nelson's syndrome and patients treated for

Table Pentetreotide scintigraphy for the detection of occult ectopic ACTH-secreting tumours

\begin{tabular}{|c|c|c|c|c|c|}
\hline \multirow[b]{2}{*}{ Reference } & \multirow[b]{2}{*}{ Primary tumour } & \multirow[b]{2}{*}{ Scan } & \multirow{2}{*}{$\begin{array}{l}\text { Tumour } \\
\text { diameter (mm) }\end{array}$} & \multicolumn{2}{|c|}{ Metastases } \\
\hline & & & & Present & Visualised \\
\hline 16 & bronchial carcinoid & + & $10 \times 15$ & + & + \\
\hline 16 & bronchial carcinoid & + & $12 \times 18$ & - & - \\
\hline 17 & bronchial carcinoid & + & 10 & + & - \\
\hline 18 & bronchial carcinoid & + & 6 & - & - \\
\hline 19 & bronchial carcinoid & + & 9 & - & - \\
\hline 20 & bronchial carcinoid & + & 6 & - & - \\
\hline 21 & bronchial carcinoid & + & 20 & - & - \\
\hline 22 & bronchial carcinoid & + & 15 & - & - \\
\hline 23 & bronchial carcinoid & + & $15 \times 18$ & - & - \\
\hline 24 & bronchial carcinoid & + & 13 & - & - \\
\hline 25 & bronchial carcinoid & + & 6 & - & - \\
\hline 26 & thymic carcinoid & + & $15 \times 20$ & - & - \\
\hline 27 & ileal carcinoid & + & ? & + & + \\
\hline 28 & $\begin{array}{l}\text { carcinoid, unknown } \\
\text { primary localisation }\end{array}$ & - & $?$ & $?$ & \\
\hline 16 & $\begin{array}{l}\text { carcinoid, unknown } \\
\text { primary localisation }\end{array}$ & - & $?$ & $?$ & \\
\hline 29 & $\begin{array}{l}\text { carcinoid, unknown } \\
\text { primary localisation }\end{array}$ & + & $?$ & + & + \\
\hline
\end{tabular}

adrenal insufficiency who are on cortisol replacement therapy only. ${ }^{8-11}$ We have also reported positive SRS in the cases of two Nelson tumours. ${ }^{7}$ The results in patients with Cushing's disease might be explained by somatostatin receptor down-regulation by hypercortisolaemia.

A variety of non-pituitary tumours are capable of ectopic secretion of proopiomelanocortin-derived peptides. These account for $10-20 \%$ of patients with Cushing's syndrome. ${ }^{2}$ Small cell lung cancer and bronchial carcinoid tumours are the commonest source of ectopic ACTH-secretion. Up to now, more than 45 cases of ectopic ACTH syndrome treated with octreotide have been reported in more than 30 studies in the medical literature. After an acute challenge with octreotide, or following short- or long-term octreotide therapy, ACTH levels decreased in most patients, or remained the same in some patients. In incidental cases, a paradoxical increase of ACTH was observed after the administration of octreotide. ${ }^{12}{ }^{13}$ Insensitivity of neuroendocrine tumours to octreotide develops in some patients, which is probably due to a preferential outgrowth of sst-negative tumour cell clones, or down-regulation of ssts. ${ }^{14}$

The localisation of an ectopic source of ACTH hypersecretion may sometimes cause diagnostic problems. In particular, bronchial carcinoid tumours may prove extremely hard to localise. Even with the use of advanced computed tomography and magnetic resonance imaging protocols, small carcinoids can be easily confused with pulmonary vascular contours. ${ }^{15}$

It may also be necessary to perform extensive scanning of the abdomen in the presence of negative imaging of the chest. ${ }^{15}$ Ourselves and others have shown that SRS can disclose occult lesions that were initially not visualised with conventional radiological techniques (table). ${ }^{16-29}$ When somatostatin analogue therapy is considered, this technique may also be used to confirm the presence of functional receptors for octapeptide somatostatin analogues as demonstrated in the study by Gill and co-workers elsewhere in this issue. ${ }^{129}$ SRS may have a negative impact on tumour staging and modification of (pre-operative and/or postoperative) management will be necessary in some of these cases. ${ }^{1}$ SRS might also be used in the follow-up of curatively operated patients, to detect regrowth of tumour remnants or newly occurring metastases at an early stage. ${ }^{1}$ However, it is important to keep in mind that, although this technique has a very high sensitivity for octapeptide receptor-positive tumours, its specificity is low. ${ }^{1}$ Also, in rare cases, tumours expressing specific ssts and tumours that do not express these receptors and therefore do not bind radiolabeled octreotide, may co-exist in the same patient. ${ }^{111}$ In-Pentetreotide can also be used in combination with a hand-held radionuclide probe for intra-operative scanning in search of tumour deposits. ${ }^{23}$

Benign or malignant adrenocortical tumours are the most common cause of ACTH-independent Cushing's syndrome, and can be found in $5-20 \%$ of patients with Cushing's syndrome. ${ }^{2}$ In contrast to animal studies, studies determining the sst status of human adrenocortical tumours are still lacking. SRS is usually not positive in all variants of the ACTH-independent Cushing's syndrome. However, in 1995, Pandha and co-workers described, in 
this journal, a favourable cortisol response to octreotide therapy in a patient with a cortisol-secreting adrenocortical carcinoma. ${ }^{30}$ Chan and co-workers could not reproduce these findings in a similar case, also reported elsewhere in this issue. ${ }^{31}$ The therapeutic use of octreotide in ACTHindependent Cushing's syndrome has not yet been clearly established.

Food-dependent, gastric inhibitory polypeptide (GIP)dependent Cushing's syndrome is a particularly rare cause of ACTH-independent Cushing's syndrome. In these patients, octreotide may only temporarily suppress non-

1 de Herder WW, Hofland LJ, van der Lely AJ, Lamberts SW. Peptide receptors in gut endocrine tumours. Baillieres Clin Gastroenterol 1996;10:571-87. 2 Orth DN. Cushing's syndrome. N Engl f Med 1995;332:791-803.

3 Lamberts SW, de Herder WW, Krenning EP, Reubi JC. A role of (labeled) somatostatin analogs in the differential diagnosis and treatment of Cushing's syndrome. F Clin Endocrinol Metab 1994;78:17-9.

4 Lamberts SW, Zuyderwiik J, den Holder F, van Koetsveld P, Hofland L. Studies on the conditions determining the inhibitory effect of somatostatin on adrenocorticotropin, prolactin and thyrotropin release by cultured rat on adrenocorticotropin, prolactin and thyrotrop in

5 pituitary cells. Neuroendocrinology 1989;50:44-50.

Stalla GK, Brockmeier SJ, Renner U, et al. Octreotide exerts different effects in vivo and in vitro in Cushing's disease. Eur F Endocrinol 1994;130:125-31. Lamberts SW, Uitterlinden P, Klijn JM. The effect of the long-acting somatostatin analogue SMS 201-995 on ACTH secretion in Nelson's syndrome

7 de Herder WW, Kwekkeboom DJ, Reijs AE, et al. Receptor scintigraphy with somatostatin analogues and dopamine antagonists of pituitary tumours. In: von Werder K, Fahlbusch R, eds Pituitary adenomas. From basic research to diagnosis and therapy. Amsterdam: Elsevier Science BV, 1996; pp 93-104

8 Lamberts SW, Uitterlinden P, Klijn JM. The effect of the long-acting somatostatin analogue SMS 201-995 on ACTH secretion in Nelson's syndrome and Cushing's disease. Acta Endocrinol 1989;120:760-6.

9 Petrini L, Gasperi M, Pilosu R, Marcello A, Martino E. Long-term treatment of Nelson's syndrome by octreotide: a case report. 7 Endocrinol Invest 1994;17:135-9.

10 Kelestimur F, Utas C, Ozbakir O, Selcuklu A, Kandemir O, Ozcan N. The effects of octreotide in a patient with Nelson's syndrome. Postgrad Med $\mathcal{F}$ 1996;72:53-4

11 Fehm HL, Voigt KH, Lang R, Beinert KE, Raptis S, Pfeiffer EF. Somatostatin: a potent inhibitor of ACTH-hypersecretion in adrenal insufficiency. Klin Wochenschr 1976;54:173-5.

12 Rieu M, Rosilio M, Richard A, Vannetzel JM, Kuhn JM. Paradoxical effect of somatostatin analogues on the ectopic secretion of corticotropin in two cases of small cell lung carcinoma. Horm Res 1993;39:207-12.

13 Duquenne M, Dousset B, Weryha G, et al. Paradoxical effect of octreotide in neoplastic inappropriate corticotropin secretion. Lancet 1991;338:1407-8.

14 de Herder WW, van der Lely AJ, Lamberts SW. Somatostatin analogue treatment of neuroendocrine tumours. Postgrad Med f 1996;72:403-8.

15 Wajchenberg BL, Mendonca B, Liberman B, Adelaide M, Pereira A Kirschner MA. Ectopic ACTH syndrome. F Steroid Biochem Mol Biol 1995; 53:139-51

16 de Herder WW, Krenning EP, Malchoff CD, et al. Somatostatin receptor scintigraphy: its value in tumor localization in patients with Cushing's syndrome caused by ectopic corticotropin or corticotropin-releasing hormone secretion. Am f Med 1994;96:305-12.

17 Weiss M, Yellin A, Husza'r M, Eisenstein Z, Bar Ziv J, Krausz Y. Localization of adrenocorticotropic hormone-secreting bronchial carcinoid tumor by somatostatin-receptor scintigraphy. Ann Intern Med 1994;121:198-9. pathological meal-induced GIP release, thereby suppressing GIP-induced cortisol secretion. ${ }^{32}$

W W DE HERDER $S$ W J LAMBERTS

Department of Internal Medicine III, University Hospital Rotterdam, Dr Molewaterplein 40, 3015 GD Rotterdam, The Netherlands

Accepted 3 November 1998

Keywords: somatostatin analogues; octreotide; Cushing's syndrome

18 Phlipponneau M, Nocaudie M, Epelbaum J, et al. Somatostatin analogs for secreting bronchial carcinoid tumor. F Clin Endocrinol Metab 1994;78:20-4.

19 Lefebvre H, Jegou S, Leroux P, Dero M, Vaudry H, Kuhn JM. Characterization of the somatostatin receptor subtype in a bronchial carcinoid tumor responsible for Cushing's syndrome. F Clin Endocrinol Metab 1995;80:1423-

20 Tsagarakis S, Giannakenas C, Vassilakos PJ, et al. Successful localization of an occult ACTH-secreting bronchial carcinoid tumor with 111 indiumDTPA labelled octreotide. Clin Endocrinol (Oxford) 1995;43:763-7.

21 Oliaro A, Filosso PL, Casadio C, et al. Bronchial carcinoid associated with Cushing's syndrome. F Cardiovasc Surg (Torino) 1995;36:511-4.

22 Briganti V, Mannelli M, La Cava G, et al. Characterizing and ectopic secreting carcinoid with indium-111-DTPA-D-Phe-pentetreotide. $f$ Nucl Med 1997;38:711-4.

23 Mansi L, Rambaldi PF, Panza N, Esposito D, Esposito V, Pastore V. Diagnosis and radioguided surgery with ${ }^{111}$ In-pentetreotide in a patient with paraneoplastic Cushing's syndrome due to a bronchial carcinoid. Eur f Endocrinol 1997;137:688-90.

24 Vallette S, Disdier P, Morange-Ramos I, et al. [Cushing syndrome disclosing bronchial neuroendocrine carcinoma: value of scintigraphy with octreotide] (in French). Rev Med Interne 1997;18:138-43.

25 Matte J, Roufosse F, Rocmans P, et al. Ectopic Cushing's syndrome and pulmonary carcinoid tumour identified by [ ${ }^{111}$ In-DTPA-D-Phe ${ }^{1}$ octreotide. Postgrad Med f 1998;74:108-10.

26 Matejka G, Toubeau M, Bernard A, Belleville Y, Vaillant G, Brun JM. Tumeur carcinoïde thymique responsable d'un syndrome de Cushing paranéoplasique. Intérêt diagnostique de la tomoscintigraphie en double marquage. Presse Med 1996;25:1201-2

27 Segu VB, Mahvi DM, Wilson MA, et al. Use of In-111 pentetreotide scintigraphy in the diagnosis of a midgut carcinoid causing Cushing's syndrome. Eur f Endocrinol 1997;137:79-83.

28 Kreisberg R. Clinical problem-solving. Half a loaf. N Engl f Med 1994;330: 1295-9.

29 Gill JR, Yong A, Power E, Ramage J. Carcinoid-associated ectopic ACTH syndrome with variable responsiveness to octreotide. Postgrad Med f $1998 ; 75: 98-100$

30 Pandha HS, Harrington K, Saini S, Lynn J, Peters M, Waxman J. Secretory symptoms from metastatic adrenal cortical carcinoma responding to octreotide. Postgrad Med F 1995;71:229-30.

31 Chan NN, Isaacs AJ. Lack of response to octreotide in Cushing's syndrome due to metastatic adrenocortical carcinoma. Postgrad Med f 1998;75:96-7.

32 de Herder WW, Hofland LJ, Usdin TB, et al. Food-dependent Cushing's syndrome resulting from abundant expression of gastric inhibitory polypeptide receptors in adrenal adenoma cells. f Clin Endocrinol Metab 1996;81:3168-72. 